\title{
Particle removal by coral reef communities: picoplankton is a major source of nitrogen
}

\author{
M. Ribes ${ }^{1,3, *}$, R. Coma ${ }^{2}$, M. J. Atkinson ${ }^{1}$, R. A. Kinzie III ${ }^{1}$ \\ ${ }^{1}$ Hawaii Institute of Marine Biology, University of Hawaii, PO Box 1346, Coconut Island, Kaneohe 96744, Hawaii, USA \\ ${ }^{2}$ Centre d'Estudis Avançats de Blanes (CEAB-CSIC), Accés Cala Sant Francesc 14, PO Box 118, 17300 Blanes, Girona, Spain \\ ${ }^{3}$ Present address: Institut de Ciències del Mar (CMIMA-CSIC), Pg. Marítim 37-49, 08003 Barcelona, Spain
}

\begin{abstract}
Removal and uptake of planktonic particulate organic matter by coral reef benthos is widely recognized as an important pathway for carbon and nutrients. We placed 3 natural assemblages of coral reef benthos, including 3 species of corals with associated sponges, ascidians, actinians, and bryozoans, in a long flume $(24 \times 0.4 \times 0.3 \mathrm{~m})$. Water was re-circulated at various speeds $(5,13,22$, and $32 \mathrm{~cm} \mathrm{~s}^{-1}$ ) over $6 \mathrm{~h}$, and the disappearance of particles (pico-, nano-, microplankton and detrital particles) were measured using flow cytometry and microscopy. Control communities consisted of dead coral skeletons. Rates of removal of all particles were proportional to their concentrations. The first-order rate constant for the decrease in particle concentration ranged from 36 to $97 \times 10^{-6} \mathrm{~m} \mathrm{~s}^{-1}$ (mean $\pm \mathrm{SD}=63 \pm 16 \times 10^{-6} \mathrm{~m} \mathrm{~s}^{-1}$ ), with $71 \%$ of this variation explained by particle type. Water velocity had no significant effect on these rate constants. Living particles contributed $96 \%$ of the total nitrogen removal, with picoplankton (cells 0.2 to $2 \mu \mathrm{m}$ ) accounting for $92 \%$. Overall, nitrogen removal from particles (8.8 to $10.3 \mathrm{mmol} \mathrm{N} \mathrm{m}^{-2} \mathrm{~d}^{-1}$ ) appears to be similar in magnitude to that of dissolved inorganic nitrogen; thus, picoplankton is a major source of nitrogen for these coral reef assemblages.
\end{abstract}

KEY WORDS: Benthos $\cdot$ Coral reef communities $\cdot$ Nutrients $\cdot$ Particle removal

\section{INTRODUCTION}

Basic relationships between rates of nutrient input and carbon production (gross, net, etc.) of coral reef ecosystems are not understood. Coral reefs obtain nutrients from overlying water either as dissolved compounds or as particulate organic matter. Despite the well-known capacity of coral reef communities to capture particles (e.g. Yonge 1963, Sorokin 1973, Johannes 1974), few studies of reef nutrient budgets have estimated the relative contribution of dissolved and particulate nutrient sources.

In the last decade, knowledge of the nature, abundance and dynamics of particles and plankton has increased dramatically, mainly due to improvements in measurement techniques (Reckermann \& Colijn 2000). It is now recognized that pico- and nanoplankton dominate planktonic biomass and production (e.g. Tremblay \& Legendre 1994). Bacteria may be the largest component of most planktonic assemblages (Cho \& Azam 1990), while autotrophic bacteria (cyanobacteria and prochlorophytes) and small flagellates constitute a significant fraction of the primary producers in many pelagic systems (Olson et al. 1990).

Most coral reef communities reside in low-nutrient tropical waters, where pico- and nanoplankton dominate planktonic communities. In these oligotrophic conditions, bacteria have been estimated to account for $30 \%$ of the total particulate carbon and autotrophic cells $<10 \mu \mathrm{m}$ for 50 to $100 \%$ of the chlorophyll a (Ferrier-Pagès \& Gattuso 1998, CISNet [Coastal Intensive Study Network] 2000: www.hawaii.edu/cisnet/). In tropical waters, particles $<10 \mu \mathrm{m}$ comprise more than $50 \%$ of the total nutrient pool (dissolved inorganic nitrogen 0.1 to $1.5 \mu \mathrm{mol} \mathrm{l}^{-1}$, particles 1.1 to $9.5 \mu \mathrm{mol} \mathrm{l}^{-1}$; Crossland \& Barnes 1983, Crossland et al. 1984).

Studies of particle-feeding by corals have traditionally focused on capture of microphytoplankton (20 to 
$200 \mu \mathrm{m}$ ) and zooplankton (Glynn 1973, Porter 1974, Sebens et al. 1996). Feeding on particulate forms, however, should also consider the capture of picoplankton ( 0.2 to $2 \mu \mathrm{m}$; including heterotrophic and autotrophic bacteria and picoeukaryotes), nanoplankton (2 to $20 \mu \mathrm{m}_{i}$ including mainly heterotrophic and autotrophic flagellates), and detritus (Ayukai 1995, Ferrier-Pagès et al. 1998, Gast et al. 1998, Yahel et al. 1998). Feeding on these smaller but more abundant particles may be the major source of nutrition to the reef systems in low-nutrient waters (Erez 1990).

Recent studies on water velocity and uptake of dissolved nutrients have shown that large-scale communities of coral reef benthos (scales of meters) are necessary to develop fully turbulent flows, typical of currents over coral reefs (Bilger \& Atkinson 1992, Hearn et al. 2001). It is also apparent that water velocity influences particle capture by suspension feeders (Shimeta \& Jumars 1991, Dai \& Lin 1993, Fabricius et al. 1995, Sebens et al. 1998), and that it is difficult to apply studies focused on individual species to community scales (e.g. Patterson 1984, Pile 1997, Ribes et al. 1998a, Sebens et al. 1998, Coma \& Ribes 2003). Heterogeneous assemblages of suspension feeders create a wide range of flow-microhabitats and capture efficiencies (Sebens et al. 1996) that cannot be simulated in studies with individual organisms. Thus, in the present study, we examined how water velocity affects particle capture by coral reef communities. We used a flume similar to that used in research on uptake of dissolved nutrients, so that a comparison between uptake of dissolved and particulate nutrients was possible.

In this study, we examined factors influencing the role of natural suspended organic particles as a nitrogen source for coral reef communities. We focused on 3 main questions: (1) what size particles are removed by the reef community from the water, and in what proportions; (2) what is the relationship between water velocity and particle removal; (3) how does nitrogen removal from particles compare with the uptake of dissolved inorganic nutrients by the same coral reef community?

\section{MATERIALS AND METHODS}

Experimental procedure. Assemblages of coral benthos comprised naturally occurring reef flat (1 to $1.5 \mathrm{~m}$ deep) benthos of Point Reef on Coconut Island, located in Kaneohe Bay on the northeast coast of Oahu, Hawaii. Living coral heads with associated fauna were collected, submerged in a bucket and placed in the experimental flume, only $10 \mathrm{~m}$ from the collection site. The 3 experimental assemblages comprised coral heads and associated fauna: Porites compressa ( $40 \pm 2$ coral heads covering $74 \pm 5 \%$ of the assemblage planar surface area, A) was the dominant species, followed by Montipora capitata $(14 \pm 2$ coral heads covering $15 \pm$ $1 \%$ of $A)$ and Pocillopora damicornis $(14 \pm 1$ coral heads covering $11 \pm 4 \%$ of $A$ ) reflecting the natural composition of corals in Kaneohe Bay (Hunter 1988). The abundance of fauna associated with coral heads was estimated by quantifying the vertical projection covered by the different taxa using a 30 by $25 \mathrm{~cm}$ quadrat divided into 750 squares of $1 \mathrm{~cm}^{2}$. All associated fauna were classified to order, except the most abundant species, which were identified to species. The taxa recorded comprised sponges, tunicates, cnidarians and bryozoans but did not include bivalves and polychaetes, due to the limitations of the nondestructive methods used to assess associated fauna abundance. The assemblages covered $2.1 \mathrm{~m}^{2}$ of the central part of the flume bottom, $4 \mathrm{~m}$ from the upstream end and $3 \mathrm{~m}$ from the downstream end. The control assemblage consisted of cleaned, sunbleached and dried, coral skeletons with the same planar surface area as the live coral assemblages, mimicking the roughness of the natural community.

The flume has an inlet pipe for fresh seawater and an outlet overflow-pipe. Except during experiments, the inlet and outlet pipes remained open so that the flume functioned as a flow-through open system with fresh seawater renewing the total volume every $25 \mathrm{~min}$. The experimental coral assemblages were maintained in the flow-through open-system mode for $4 \mathrm{~d}$ before the experiments began. This open mode was also used during the periods between experiments: $20 \mathrm{~min}$ before the beginning of each experiment the volume of water in the flume was completely replaced by increasing the renewal rate of the seawater $(8 \mathrm{~min}$ replacement time); immediately after this $20 \mathrm{~min}$ flushing period, the inlet pipe was closed and the outlet was adjusted to reduce the water height to $24 \mathrm{~cm}$, corresponding to a total volume of about $2.6 \mathrm{~m}^{3}$. At the beginning of an experimental run, the overflow was closed so that the flume was operated in a closed-flow mode, and initial water samples were collected for all naturally occurring particles. For each experiment, 5 to 7 water samples were collected every 40 to $55 \mathrm{~min}$ intervals over a $6 \mathrm{~h}$ period to measure particle concentration. At each sampling, $5 \mathrm{l}$ of water were collected from the flume with a Niskin bottle. To remove larger particles, water samples were first screened with a $335 \mu \mathrm{m}$-mesh net, then immediately preserved for further analysis.

Experiments were conducted between 09:00 and 16:00 h. Temperatures were recorded at $10 \mathrm{~min}$ intervals within the flume during each experimental run. Temperatures on the reef flat where the assemblages were collected, were also recorded during the experi- 
ments. After each experimental run, inlet and outlet pipes were opened so that the flume was returned to an open flow-through system, and the walls of the flume were scrubbed to remove any microbial growth.

We measured 2 physical parameters during each experiment to characterize the water flow: water velocity and change in head, or height, of the water. Water velocity was measured by timing a neutrally buoyant drogue as it passed over the full length of the assemblage at least 10 times for each flow. The order of the runs at the different water velocities $(5,13,22$ and $32 \mathrm{~cm} \mathrm{~s}^{-1}$ ) was randomly selected. The change in height of the water was measured using Pitot tubes and a micrometer (Baird \& Atkinson 1997). The change in head is a measure of the loss of energy due to friction by the bottom (Bilger \& Atkinson 1992, Baird \& Atkinson 1997). From the change in head and water velocity, we calculated 2 parameters: (1) a friction coefficient $\left(c_{f}\right)$ to describe the effect of the rough bottom on the flow:

$$
\mathrm{C}_{f}=2 g h s / U_{b}^{2}
$$

where $g$ is acceleration from gravity (which is $9.8 \mathrm{~m}$ $\left.\mathrm{s}^{-2}\right), h$ is the height of the water, $s$ is the slope of the water above the assemblage, and $U_{b}$ is the bulk velocity (see Baird \& Atkinson 1997); and (2) the Reynolds number of the flow:

$$
\operatorname{Re}=U_{b} 4 h / v
$$

where $v$ is the kinematic viscosity of seawater at $25^{\circ} \mathrm{C}$ $\left(0.9410^{-6} \mathrm{~m}^{2} \mathrm{~s}^{-1}\right)$. Topographic relief was also estimated by laying a chain (link-length $0.5 \mathrm{~cm}$ ) along the surface of the reef and calculating the ratio of the length of this chain to the planar length of the assemblage 4 times for each assemblage (Loya 1978).

To determine the natural abundance of the different components of the planktonic communities in Kaneohe Bay, sampling was conducted every 2 wk between March and December 2000 in a location in central Kaneohe Bay. Samples were collected at $0.5 \mathrm{~m}$ depth with a suction pump. Data on total (particulate organic nitrogen) (PON) are the average of biweekly sampling between November 1998 and August 2000 (CISNet 2000).

Particle-assessment protocol. We separated particulate organic matter (POM) into 2 groups: live POM and dead, or detrital POM. Live POM was partitioned into different cell types, which were quantified using existing methods. These cell types are heterotrophic bacteria, Prochlorococcus sp., Synechococcus sp., picoeukaryotes (mainly composed of naked flagellates $<2 \mu \mathrm{m}$ ), nanoeukaryotes (mainly composed of naked flagellates $>2 \mu \mathrm{m}$, small dinoflagellates and coccolithophores), phytoplankton (which mainly include diatoms, dinoflagellates) and ciliates.
We used flow cytometry (a B\&D FACScalibur bench machine with a laser emitting at $488 \mathrm{~nm}$ ) to quantify heterotrophic bacteria, Prochlorococcus sp., Synechococcus sp., and picoeukaryotes. Water samples $(2 \mathrm{ml})$ were fixed with $1 \%$ paraformaldehyde $+0.05 \%$ glutaraldehyde (final concentration) and frozen in liquid nitrogen; afterwards, they were stored at $-80^{\circ} \mathrm{C}$ or in dry ice. Heterotrophic bacteria were stained with Syto 13 (Molecular Probes) at $2.5 \mu \mathrm{M}$ and run at low speed (approx. $18 \mu \mathrm{l} \mathrm{min}{ }^{-1}$ ). They were detected by their signature in a plot of side-scatter versus green fluorescence. For the detection of Prochlorococcus sp., Synechococcus sp. and picoeukaryotes, we ran the sample again without staining and at high speed

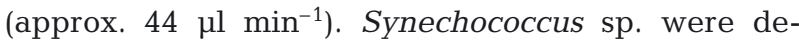
tected by their signature in a plot of orange fluorescence versus red fluorescence. The same signatures were used for Prochlorococcus sp. and picoeukaryotes, with the knowledge that Prochlorococcus sp. had low red fluorescence and no orange fluorescence, and picoeukaryotes had high red fluorescence and no orange fluorescence (further details can be obtained from Gasol \& Morán 1999). Nanoeukaryote abundance was determined on $20 \mathrm{ml}$ subsamples stained with DAPI and filtered through a $0.2 \mu \mathrm{m}$ filter (Nuclepore). Stained cells were directly enumerated using epifluorescence microscopy. Cell sizes of heterotrophic bacteria, Synechococcus sp., picoeukaryotes, and nanoeukaryotes were measured on the same filters.

To quantify phytoplankton and ciliate cell numbers, $350 \mathrm{ml}$ water samples were preserved with Lugol's solution ( $1 \%$ final concentration). Subsamples of $100 \mathrm{ml}$ were transferred to settling chambers, and the major groups of nano- and microphytoplankton were quantified using an inverted microscope. Cell sizes (length and width) were measured with an ocular micrometer. Cell biovolumes were estimated from the length and width measurements, assuming the nearest geometrical shape (Edler 1979). Nitrogen content (N) was estimated using conversion factors from the literature. For heterotrophic bacteria $3.8 \mathrm{fg} \mathrm{N} \mathrm{cell}^{-1}$, for Synechococcus sp. $50 \mathrm{fgN}^{-1} \mathrm{cel}^{-1}$, for pico- and nanoeukaryotes $26.1{\mathrm{fg} \mathrm{N} \mathrm{m}^{-3}}^{-3}$ (Caron et al. 1995). For phytoplankton, biovolume $\left(V, \mu \mathrm{m}^{3}\right)$ was converted to nitrogen $(\mathrm{N})$ weight using the equation: $\mathrm{pg} \mathrm{N} \mathrm{cell}^{-1}=$ $0.0172\left(\mu \mathrm{m}^{3}\right)^{1.023}$ (Montagnes et al. 1994).

PON was measured by filtering $1 \mathrm{l}$ water samples on pre-combusted glass-fiber filters (Whatman GF/F 1825 025). The filters were kept frozen at $-80^{\circ} \mathrm{C}$ until analysis. Prior to analysis, filters were dried at $60^{\circ} \mathrm{C}$ for $24 \mathrm{~h}$ and analyzed with a CHN autoanalyser (Perkin-Elmer 240). PON measurements included both detrital and live nitrogen. Detrital PON was estimated as the difference between total PON (C:H:N analysis) and total 
live nitrogen (estimated from cell counts and measurements: Wotton 1990).

The effect of water velocity and particle type on removal rate constants was tested using a repeatedmeasures multivariate analysis of variance (MANOVA) with 2 within-subjects factors (water velocity and particle type), followed by Fisher's least-significant difference (LSD) post-hoc test (Zar 1996). Analysis of variance assumptions for normality and heteroscedasticity, examined with a Kolmogorov-Smirnov test and Levene's test respectively, were fulfilled. Statistical analyses were done using STATISTICA for Windows (version 5.1, 1998; StatSoft).

\section{RESULTS}

Water temperatures of the flume experiments varied between 24 and $29^{\circ} \mathrm{C}$ (Table 1), similar to temperatures on Point Reef $\left(\chi^{2}=0.67, \mathrm{p}<0.02 ;\right.$ mean $=25.5 \pm 1.1 \mathrm{SD}$ and $25.9 \pm 1.7 \mathrm{SD}$ for flume and reef, respectively). Water velocities for the 3 experimental communities were nominally 5, 13, 22 and $32 \mathrm{~cm} \mathrm{~s}^{-1}$ and varied by only $10 \%$, giving Reynolds numbers for the flows between 51000 and 345000 (Table 1). Friction factors, $\left(C_{f}\right)$ of the communities at $5 \mathrm{~cm} \mathrm{~s}^{-1}$ were not detectable (head $<1 \mathrm{~mm}$ ) giving an unrealistic wide range of values (nm in Table 1), whereas at higher velocities (13 to $\left.32 \mathrm{~cm} \mathrm{~s}^{-1}\right) C_{f}$ varied over in a realistic range of 0.07 to 0.08 (Table 1). These flows were thus turbulent, supporting rapid vertical mixing in the flowing water. The bottom of the flume was covered mostly with Porites compressa (67 to $77 \%$ ), the next most abundant coral was Montipora capitata (14 to $17 \%$ ) and the least abundant was Pocillopora damicornis (8 to 16\%: Table 1) Approximately 50 to $65 \%$ of the P. compressa polyps were extended during the experiment, but only $10 \%$ for $M$. capitata and $P$. damicornis, giving a total surface area of extended polyps between 65 and $85 \%$.

Sponges were the dominant active suspension-feeding animals in the fauna associated with coral heads of the experimental assemblages. They covered a mean $( \pm \mathrm{SD})$ surface area ranging from 310 to 710 (490 \pm 200) $\mathrm{cm}^{2}$ per assemblage. The species Biemna fistulosa accounted for $60 \pm 23 \%$ of this. Ascidian abundance consisted of 13 to $71(33 \pm 33) \mathrm{cm}^{2}$ colonial ascidians and 24 to $44(33 \pm 10) \mathrm{cm}^{2}$ solitary ascidians per assemblage. Brotryllus sp. and Polyclinum sp. were the dominant colonial ascidians and Phallusia nigra, Herdmania momus and Ciona intestinalis the dominant solitary ascidians. Actinians were the most abundant passive suspension feeder in the associated fauna, ranging from 15 to 75 (36 $\pm 33 \mathrm{SD})$ individuals per assemblage. Aiptasia pulchella was the dominant actinian species. Very few bryozoans were found. Thus, both corals and associated suspension feeders were capable of removing particles from the flowing water.

Natural particles in Kaneohe Bay were dominated by prokaryotes. Of the prokaryotes, there were 10-fold more heterotrophic bacteria $\left(23 \times 10^{5}\right.$ cells ml $\left.{ }^{-1}\right)$ than Synechococcus sp. $\left(2.6 \times 10^{5}\right.$ cells $\left.\mathrm{ml}^{-1}\right)$; picoeukaryote abundance was 2 orders of magnitude less than that of Synechococcus sp. $\left(15 \times 10^{3}\right.$ cells $\left.\mathrm{ml}^{-1}\right)$. Nanoeukaryotes were much lower in concentration, at 200 cells

Table 1. Conditions of flume experiments for the 3 assemblages (Ass) and Controls (Ctrl): temperature, water velocity ( $U_{i} \mathrm{~cm} \mathrm{~s}^{-1}$ ), Reynolds numbers $\left(\operatorname{Re} \times 10^{3}\right.$ ) and friction coefficient $\left(C_{f}\right)$ (Re and $C_{f}$ are dimensionless). Percentage of planar surface area of the flume covered by each species is also shown (PC: Porites compressa; Mc: Montipora capitata; Pd: Pocillopora damicornis). TR: mean topographic relief; nm: not measurable

\begin{tabular}{|c|c|c|c|c|c|c|c|c|c|}
\hline \multirow[t]{2}{*}{ Ass } & \multicolumn{2}{|c|}{ Temp. $\left({ }^{\circ} \mathrm{C}\right)$} & \multirow[t]{2}{*}{$U_{b}$} & \multirow[t]{2}{*}{$\mathrm{Re}$} & \multirow[t]{2}{*}{$C_{f}$} & \multirow[t]{2}{*}{$\% P_{C}$} & \multirow[t]{2}{*}{$\% M C$} & \multirow[t]{2}{*}{$\% P d$} & \multirow[t]{2}{*}{ TR } \\
\hline & Min. & Max. & & & & & & & \\
\hline Ctrl & 25.2 & 27.3 & 6 & 59 & $\mathrm{~nm}$ & 76 & 14 & 10 & 1.4 \\
\hline Ctrl & 23.7 & 27.0 & 13 & 109 & 0.041 & 76 & 14 & 10 & 1.4 \\
\hline Ctrl & 25.2 & 27.6 & 22 & 228 & 0.048 & 76 & 14 & 10 & 1.4 \\
\hline Ctrl & 23.3 & 24.4 & 34 & 345 & 0.049 & 76 & 14 & 10 & 1.4 \\
\hline 1 & 24.1 & 27.1 & 5 & 51 & $\mathrm{~nm}$ & 67 & 17 & 16 & 1.6 \\
\hline 1 & 24.3 & 24.6 & 12 & 107 & 0.077 & 67 & 17 & 16 & 1.6 \\
\hline 1 & 24.1 & 24.9 & 22 & 203 & 0.068 & 67 & 17 & 16 & 1.6 \\
\hline 1 & 23.8 & 26.3 & 33 & 296 & 0.073 & 67 & 17 & 16 & 1.6 \\
\hline 2 & 24.7 & 26.7 & 6 & 57 & $\mathrm{~nm}$ & 77 & 14 & 9 & 1.7 \\
\hline 2 & 24.1 & 28.7 & 12 & 121 & 0.067 & 77 & 14 & 9 & 1.7 \\
\hline 2 & 24.0 & 24.7 & 22 & 219 & 0.071 & 77 & 14 & 9 & 1.7 \\
\hline 2 & 23.9 & 26.2 & 31 & 310 & 0.083 & 77 & 14 & 9 & 1.7 \\
\hline 3 & 25.4 & 28.9 & 6 & 56 & $\mathrm{~nm}$ & 77 & 15 & 8 & 1.6 \\
\hline 3 & 24.6 & 28.5 & 12 & 121 & 0.070 & 77 & 15 & 8 & 1.6 \\
\hline 3 & 25.0 & 28.8 & 22 & 224 & 0.079 & 77 & 15 & 8 & 1.6 \\
\hline 3 & 26.2 & 27.0 & 33 & 327 & 0.097 & 77 & 15 & 8 & 1.6 \\
\hline
\end{tabular}


$\mathrm{ml}^{-1}$. Microplankton (diatoms dinoflagellates and ciliates) comprised a very small proportion of the particles, only 10 to 30 cells $\mathrm{ml}^{-1}$ (Table 2). Prochlorococcus sp. was not found during the experiments, and is generally uncommon in Kaneohe Bay.

In experiments with live corals, concentrations of all particle types (heterotrophic bacteria, Synechococcus sp., picoeukaryotes, nanoeukaryotes, diatoms [Chaetoceros sp., Rhizosolenia sp. and Nitzschia sp.], dinoflagellates and ciliates), decreased in all experiments (e.g. Fig. 1, Table 3). The decrease in concentration of each particle type was exponential $\left(\mathrm{e}^{-k t}\right)$, indicating that the rate of removal slowed as the concentration or biomass of the particles
Table 2. Natural abundance (mean \pm SD) of different components of planktonic communities in Kaneohe Bay water during study period, showing cell size and nitrogen contribution of planktonic communities and detritus. Detrital particulate organic carbon (PON) includes all detrital particles $<335 \mu \mathrm{m}$. Dissolved inorganic nitrogen values from CISNet (Coastal Intensive Study Network) (2000: www.hawaii.edu/cisnet/). Het: heterotrophic

\begin{tabular}{|lcccc|}
\hline Particle type & Cells ml $^{-1}$ & Size $(\mu \mathrm{m})$ & $\mu \mathrm{g} \mathrm{N} \mathrm{l}^{-1}$ & $\mu \mathrm{mol} \mathrm{N}{ }^{-1}$ \\
\hline Het. bacteria & $23 \pm 6 \times 10^{5}$ & $0.5 \pm 0.2$ & $8 \pm 2$ & $0.61 \pm 0.17$ \\
Synechococcus sp. & $3 \pm 1 \times 10^{5}$ & $1.2 \pm 0.6$ & $13 \pm 5$ & $0.92 \pm 0.38$ \\
Picoeukaryotes & $15 \pm 7 \times 10^{3}$ & $1.4 \pm 0.3$ & $0.6 \pm 0.3$ & $0.04 \pm 0.02$ \\
Nanoeukaryotes & $222 \pm 190$ & $3.3 \pm 0.7$ & $0.1 \pm 0.1$ & $0.01 \pm 0.01$ \\
Diatoms & $29 \pm 11$ & $30 \pm 16$ & $0.6 \pm 0.2$ & $0.04 \pm 0.02$ \\
Dinoflagellates & $9 \pm 3$ & $20 \pm 7$ & $0.3 \pm 0.1$ & $0.02 \pm 0.01$ \\
Ciliates & $4 \pm 1$ & $22 \pm 10$ & $0.3 \pm 0.1$ & $0.03 \pm 0.01$ \\
Total live particles & & & 23 & 1.66 \\
Detrital PON & & & $30 \pm 10$ & $2.14 \pm 0.71$ \\
Total PON & & & $3 \pm 3$ & $0.19 \pm 0.19$ \\
$\mathrm{NH}^{+}$ & & & $2 \pm 5$ & $0.15 \pm 0.36$ \\
$\mathrm{NO}_{3}{ }^{-}$ & & & & \\
\hline
\end{tabular}
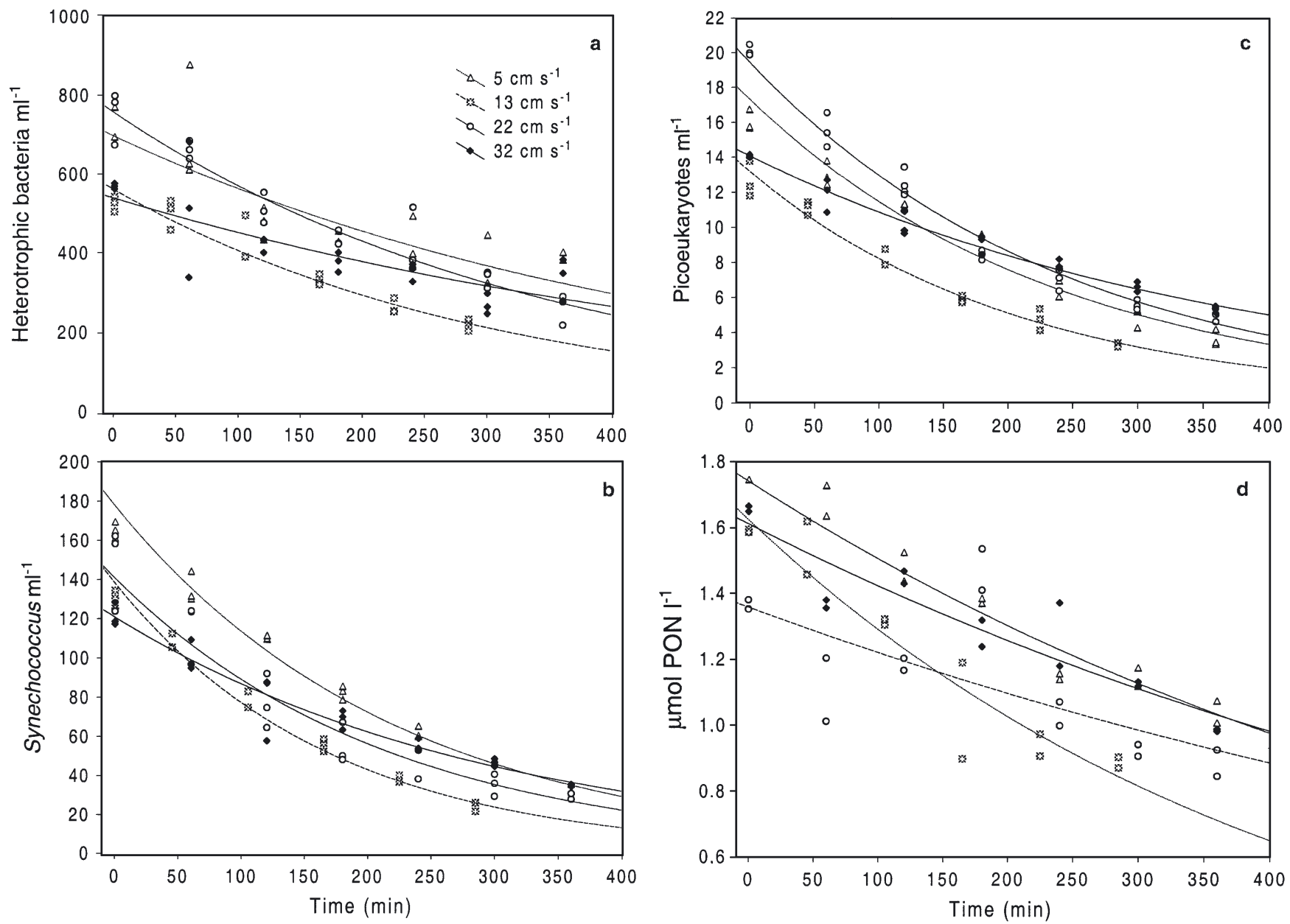

Fig. 1. Concentration of cells $\left(\times 10^{3} \mathrm{ml}^{-1}\right)$ for heterotrophic bacteria, Synechococcus sp. and concentration of picoeukaryotes and PON (particulate organic nitrogen) versus time at 4 water velocities. Curvature shows that rate of removal slows as concentration decreases 
Table 3. Regression analysis between $\ln$ particle concentration and time for each assemblage and water velocity ( $\mathrm{cm} \mathrm{s}^{-1}$ ), lower and upper $95 \%$ confidence limits of regression, $\mathrm{r}^{2}$, and probability. Abbreviations as in Fig. 3 and Table 4 . All $S$ values were negative except for HB and Syn of control assemblages at $5 \mathrm{~cm} \mathrm{~s}^{-1}{ }^{* *} \mathrm{p}<0.01$; ${ }^{*} \mathrm{p}<0.05$; ns: not significant. HB: heterotrophic bacteria; Syn: Synechococcus sp.; Pk: picoeukaryotes; Nk: nanoeukaryotes; Mic: microplankton (diatoms, dinoflagellates and ciliates)

\begin{tabular}{|c|c|c|c|c|c|c|c|c|c|c|c|c|c|c|c|c|}
\hline \multirow{2}{*}{$\begin{array}{l}\text { Water velocity } \\
\text { Particle } \\
\text { type }\end{array}$} & \multicolumn{4}{|c|}{ Control } & \multicolumn{4}{|c|}{ Assemblage 1} & \multicolumn{4}{|c|}{ Assemblage 2} & \multicolumn{4}{|c|}{ Assemblage 3} \\
\hline & $S$ & Lower & Upper & $r r^{2}$ & $S$ & Lower & Uppe & er $r^{2}$ & $S$ & Lower & Uppe & $r r^{2}$ & $S$ & Lowe & r Upp & er $r^{2}$ \\
\hline \multicolumn{17}{|l|}{$5 \mathrm{~cm} \mathrm{~s}^{-1}$} \\
\hline $\mathrm{HB}$ & 16 & 4 & 28 & $0.92^{* *}$ & 31 & 20 & 42 & $0.39^{* *}$ & 50 & 44 & 56 & $0.87^{* *}$ & 60 & 48 & 72 & $0.75^{* *}$ \\
\hline Syn & 9 & 6 & 13 & $0.45^{*}$ & 59 & 42 & 76 & $0.83^{* *}$ & 61 & 56 & 66 & $0.95^{* *}$ & 98 & 94 & 102 & $0.98^{* *}$ \\
\hline $\mathrm{Pk}$ & 7 & -27 & 42 & $0.04^{\mathrm{ns}}$ & 81 & 53 & 109 & $0.71^{* *}$ & 61 & 55 & 67 & $0.94^{* *}$ & 81 & 73 & 89 & $0.96^{* *}$ \\
\hline $\mathrm{Nk}$ & 43 & -62 & 147 & $0.19^{\text {ns }}$ & 37 & -27 & 100 & $0.40^{*}$ & 41 & -25 & 102 & $0.52^{*}$ & 52 & -14 & 118 & $0.67^{* *}$ \\
\hline Mic & 2 & 1 & 3 & $0.06^{\mathrm{ns}}$ & 42 & 26 & 58 & $0.78^{* *}$ & 34 & 30 & 38 & $0.90^{* *}$ & 33 & 9 & 57 & $0.88^{* *}$ \\
\hline PON & 15 & 10 & 20 & $0.78^{* *}$ & 24 & 16 & 33 & $0.83^{* *}$ & 13 & 9 & 17 & $0.78^{* *}$ & 28 & 24 & 33 & $0.92^{* *}$ \\
\hline \multicolumn{17}{|l|}{$13 \mathrm{~cm} \mathrm{~s}^{-1}$} \\
\hline $\mathrm{HB}$ & 1 & -22 & 24 & $0.02^{\mathrm{ns}}$ & 63 & 47 & 79 & $0.73^{* *}$ & 28 & 24 & 32 & $0.89^{* *}$ & 32 & 24 & 40 & $0.94^{* *}$ \\
\hline Syn & 4 & -12 & 20 & $0.003^{\mathrm{ns}}$ & 66 & 54 & 78 & $0.95^{* *}$ & 52 & 40 & 64 & $0.94^{* *}$ & 99 & 91 & 107 & $0.99^{* *}$ \\
\hline $\mathrm{Pk}$ & 4 & -48 & 57 & $0.29^{\mathrm{ns}}$ & 96 & 57 & 135 & $0.71^{* *}$ & 61 & 54 & 68 & $0.91^{* *}$ & 93 & 89 & 97 & $0.98^{* *}$ \\
\hline $\mathrm{Nk}$ & 4 & -26 & 34 & $0.01^{\mathrm{ns}}$ & 55 & 27 & 83 & $0.89^{* *}$ & 70 & 42 & 98 & $0.70^{* *}$ & 73 & 45 & 101 & $0.72^{* *}$ \\
\hline Mic & 41 & -7 & 88 & $0.16^{\mathrm{ns}}$ & 37 & 28 & 46 & $0.86^{* *}$ & 59 & 50 & 68 & $0.83^{* *}$ & 41 & 29 & 53 & $0.60^{* *}$ \\
\hline PON & 43 & -19 & 104 & $0.20^{\mathrm{ns}}$ & 22 & 2 & 43 & $0.45^{*}$ & 12 & 3 & 20 & $0.34^{*}$ & 47 & 37 & 57 & $0.88^{* *}$ \\
\hline \multicolumn{17}{|l|}{$22 \mathrm{~cm} \mathrm{~s}^{-1}$} \\
\hline $\mathrm{HB}$ & 16 & -16 & 49 & $0.14^{\mathrm{ns}}$ & 55 & 40 & 70 & $0.81^{* *}$ & 43 & 39 & 47 & $0.96^{* *}$ & 50 & 42 & 58 & $0.91^{* *}$ \\
\hline Syn & 18 & -24 & 61 & $0.15^{\mathrm{ns}}$ & 92 & 69 & 115 & $0.88^{* *}$ & 81 & 77 & 85 & $0.99^{* *}$ & 73 & 61 & 85 & $0.93^{* *}$ \\
\hline $\mathrm{Pk}$ & 8 & -65 & 81 & $0.04^{\mathrm{ns}}$ & 116 & 64 & 168 & $0.71^{* *}$ & 81 & 77 & 85 & $0.98^{* *}$ & 94 & 86 & 102 & $0.97^{* *}$ \\
\hline $\mathrm{Nk}$ & 2 & -81 & 85 & $0.01^{\mathrm{ns}}$ & 69 & 29 & 109 & $0.83^{* *}$ & 51 & 11 & 91 & $0.78^{* *}$ & 61 & 45 & 77 & $0.63^{* *}$ \\
\hline Mic & 4 & -16 & 24 & $0.08^{\text {ns }}$ & 41 & 17 & 65 & $0.78^{* *}$ & 58 & 42 & 74 & $0.67^{* *}$ & 72 & 68 & 76 & $0.81^{* *}$ \\
\hline PON & 5 & -21 & 30 & $0.10^{\text {ns }}$ & 41 & 9 & 73 & $0.59^{*}$ & 24 & 19 & 30 & $0.87^{* *}$ & 20 & 8 & 32 & $0.46^{*}$ \\
\hline \multicolumn{17}{|l|}{$32 \mathrm{~cm} \mathrm{~s}^{-1}$} \\
\hline $\mathrm{HB}$ & 14 & -2 & 30 & $0.02^{\text {ns }}$ & 55 & 31 & 79 & $0.60^{* *}$ & 50 & 42 & 58 & $0.91^{* *}$ & 49 & 37 & 61 & $0.63^{* *}$ \\
\hline Syn & 2 & -27 & 30 & $0.05^{\mathrm{ns}}$ & 77 & 42 & 112 & $0.97^{* *}$ & 81 & 75 & 88 & $0.97^{* *}$ & 61 & 53 & 69 & $0.95^{* *}$ \\
\hline $\mathrm{Pk}$ & 4 & -32 & 40 & $0.13^{\mathrm{ns}}$ & 82 & 49 & 115 & $0.76^{* *}$ & 81 & 76 & 87 & $0.98^{* *}$ & 61 & 57 & 65 & $0.97^{* *}$ \\
\hline $\mathrm{Nk}$ & 1 & -14 & 16 & $0.001^{\mathrm{ns}}$ & 55 & 36 & 74 & $0.86^{* *}$ & 61 & 41 & 81 & $0.61^{* *}$ & 70 & 46 & 94 & $0.55^{* *}$ \\
\hline Mic & 1 & -37 & 39 & $0.08^{\text {ns }}$ & 60 & 52 & 68 & $0.79^{* *}$ & 55 & 47 & 63 & $0.96^{* *}$ & 74 & 73 & 75 & $0.65^{*}$ \\
\hline PON & 1 & -10 & 12 & $0.10^{\mathrm{ns}}$ & 18 & 4 & 33 & $0.55^{*}$ & 37 & 28 & 45 & $0.85^{* *}$ & 20 & 15 & 26 & $0.86^{* *}$ \\
\hline
\end{tabular}

decreased (Fig. 1). The rate constant for the rate of removal can be calculated by plotting $\ln \left(\right.$ cell $\left.\mathrm{ml}^{-1}\right)$ versus time and determining the slope (Fig. 2). The slope $\left(\right.$ in $\left.\min ^{-1}\right)$, times the water volume/planar surface-area $\times \operatorname{min~s}^{-1}$ gives a rate constant, $S$, in units of $\mathrm{m} \mathrm{s}^{-1}$. For live communities, $S$ varied by a factor of 3.7 between 31 and $116 \times 10^{-6} \mathrm{~m} \mathrm{~s}^{-1}\left(63 \pm 16 \times 10^{-6} \mathrm{~m} \mathrm{~s}^{-1} ; 3\right.$ to $8 \mathrm{~m}$ $\mathrm{d}^{-1}$; Table 3). Assemblages of coral skeletons, used as controls, generally had non-significant slopes between ln concentration and time (Fig. 2, Table 3). This result clearly indicates that particles could not be removed from the water by physical trapping in baffles or cavities within the control community. In contrast, however, during the experiment at $5 \mathrm{~cm} \mathrm{~s}^{-1}$ the control for heterotrophic bacteria and Synechococcus sp. significantly increased (Table 3).

Particle type contributed the largest variation to $S$ (71\%; Table 4). $S$ values showed that Synechococcus sp. and picoeukaryotes were removed more efficiently $\left(80 \pm 16 \times 10^{-6} \mathrm{~m} \mathrm{~s}^{-1}\right)$ than smaller particles such as heterotrophic bacteria and larger particles such as nanoeukaryotes, microplankton $\left(51 \pm 16 \times 10^{-6} \mathrm{~m} \mathrm{~s}^{-1}\right)$ and detrital particles (Table 3 ). $S$ did not show a trend with water velocity (Table 3 , Fig. 3 ). The $\mathrm{N}$ removal rate is $S \times$ the amount of nitrogen per cell $\times$ the number of cells in each particle type (Table 2). Live particles accounted for $96 \pm 2 \%$ of the total nitrogen removal (Fig 4). Picoplankton (cells $<2 \mu \mathrm{m}$ ), which comprises heterotrophic bacteria, Synechococcus sp. and picoeukaryotes, accounted for $92 \pm 1 \%$ SD of the total nitrogen removal from particles (Fig. 5). Microplankton, detrital particles and nanoplankton accounted for only about $4 \pm 0.8 \%, 4 \pm 1 \%$ and $0.3 \pm 0.05 \% \mathrm{SD}$, respectively (Fig. 5). There were no significant changes in these proportions with water velocity. Thus picoplankton were the major source of particulate nitrogen, representing about $9 \mathrm{mmol} \mathrm{N} \mathrm{m}^{-2} \mathrm{~d}^{-1}$.

\section{DISCUSSION}

There were no significant decreases in concentration of cells in the control experiments; however, at the slowest water velocity $\left(5 \mathrm{~cm} \mathrm{~s}^{-1}\right)$ there was a slight sig- 

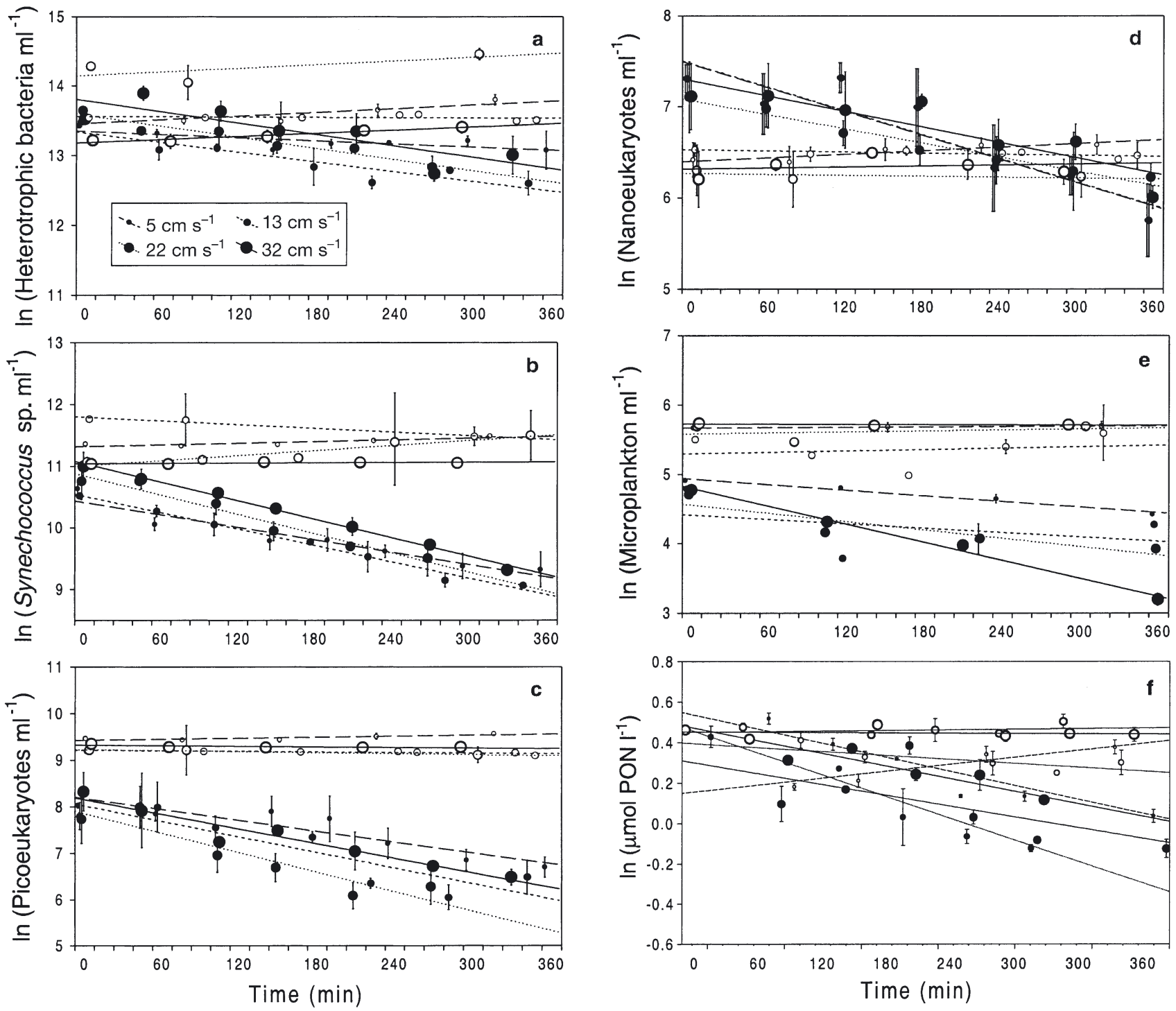

Fig. 2. Mean $( \pm \mathrm{SD})$ ln concentration of particles for all particle types versus time for all water velocities. $(\bullet)$ Experiments with live coral assemblages, (O) controls (clean coral skeletons)

nificant increase in heterotrophic bacteria and Synechococcus sp. of about 40 and $35 \%$, respectively (Table 3, Fig. 2). The experiments were over in 6 h, so assuming a doubling time of once per day, it is possible that cells could have increased the observed amount through natural growth of the cells in the flowing water, or side walls of the flume $\left(2^{6 / 24}=20 \%\right.$ : Button 1994, Sherr et al. 1999). In principle, this amount of bacteria and Synechococcus sp. cells could be added to the uptake, increasing the uptake rate by about $10 \%$. However, we concluded that the exchange (both production of cells from biofilms and their removal) with inert surfaces such as the side walls of the flume and inert coral structures was small, and did not affect the overall estimates of uptake. Another source of error was the actual release of zooxanthellae cells (small dinoflagellates) during the course of the experiment (Stimson \& Kinzie 1991). In principle, this source of cells could create a major change in particle numbers in the flowing water; however in our experiments dinoflagellates comprised a negligible component of the particulate nitrogen (Fig. 5).

The removal of particles was proportional to the concentration of cells (first-order), meaning that the higher the concentration of particles, the faster the removal rate. This result could arise from 2 circumstances: (1) particles could passively stick to coral mucus; (2) active filtering and assimilation by sponges and ascidians could occur. Mucus in the water column or attached to corals can trap particles such as pico-, 
Table 4. Repeated-measures MANOVA with 2 within-subjects factors (variable is rate constant $S\left[\mathrm{~m} \mathrm{~s}^{-1}\right]$ and the 2 factors are water velocity and particle type) and Fisher's least-significant difference (LSD) post-hoc test. Probability values $<0.05$ have been considered significant. Abbreviations as in Table 3

\begin{tabular}{|c|c|c|c|c|c|c|}
\hline $\begin{array}{l}\text { MANOVA } \\
\text { Factor }\end{array}$ & df factor & MS factor & df error & MS error & $F$ & $\mathrm{p}$ \\
\hline Water velocity & 3 & 439 & 6 & 319 & 1.38 & 0.3370 \\
\hline Particle type & 4 & 3186 & 8 & 247 & 12.88 & 0.0015 \\
\hline Interaction & 12 & 156 & 24 & 109 & 1.43 & 0.2211 \\
\hline \multirow[t]{3}{*}{ LSD post-hoc } & \multicolumn{6}{|c|}{$S$ values } \\
\hline & $\mathrm{HB}$ & Syn & $\mathrm{Pk}$ & $\mathrm{Nk}$ & & Mic \\
\hline & 47 & 75 & 82 & 58 & & 50 \\
\hline \multicolumn{7}{|l|}{$\mathrm{HB}$} \\
\hline Syn & 0.0015 & & & & & \\
\hline $\mathrm{Pk}$ & 0.0004 & 0.2987 & & & & \\
\hline $\mathrm{Nk}$ & 0.1119 & 0.0183 & 0.003 & & & \\
\hline Mic & 0.4363 & 0.0044 & 0.001 & 0.362 & & \\
\hline
\end{tabular}

nano-, microplankton and detrital POM (Muscatine 1973, Lewis \& Price 1975, Alldredge \& Silver 1988), removing them from the water column and depositing them on the reef benthos, where some of the particles may be ingested via ciliary-mucoid feeding (Muscatine 1973). If this mechanism were the dominative mechanism, we would expect an increase in removal rates with increased water velocity, as more suspended particles encountered collisions with mucus surfaces. However, we observed only a modest non-significant increase in removal rates ( $S$, Fig. 3 ) with water velocity and actually a slight decrease at the highest velocity; thus we suggest that adhesion to mucus was probably

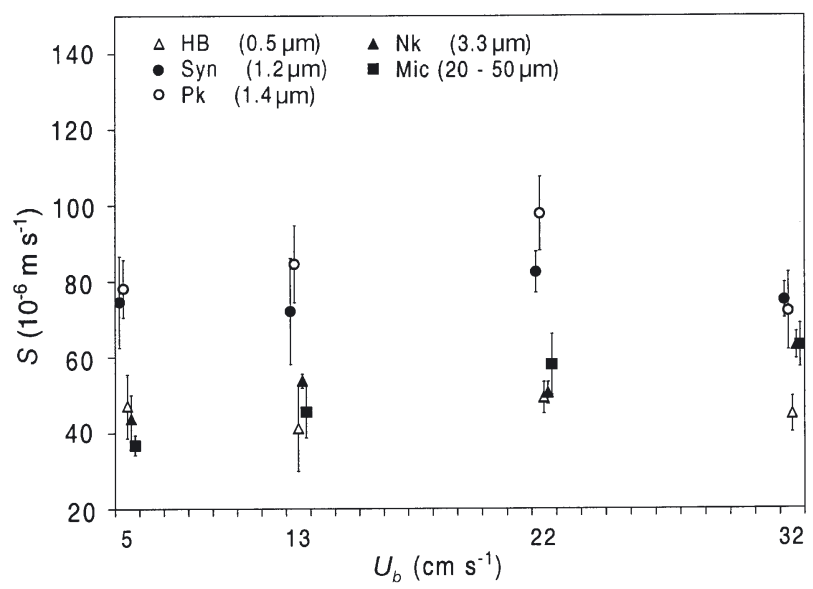

Fig. 3. First-order rate constant (means $\pm \mathrm{SD}$ ) for removal of plankton ( $S$ : slope of graphs in Fig. $2 \times$ water volume/planar surface area of benthos in the flume) versus water velocity $\left(U_{b}\right)$ for different particles. HB: heterotrophic bacteria; Syn: Synechococcus sp.; Pk: picoeukaryotes; Nk: nanoeukaryotes, Mic (microplankton) comprises diatoms, dinoflagellates and ciliates not the major mechanism of cell removal.

The second method of removal, capture by benthic filter-feeders, requires abundance of sponges and ascidians that capture and assimilate pico-, nano-, microplankton and detrital POM (e.g. Reiswig 1971, Klumpp 1984, FialaMedioni 1987, Pile 1997, Ribes et al. 1999). The abundance of associated fauna in our assemblages appears high in comparison with those observed in reef surveys in the Red Sea (16 ascidians $\mathrm{m}^{-2}$ in this study vs 2 ascidians $\mathrm{m}^{-2}$ mean density in Yahel et al. 1998), for which it is widely suggested that reefs are supported by exchange with particles (Genin et al. 2002). These high densities may be due to a higher abundance of associated fauna at our study site, or may be related to the limitations of the in situ visual count method used in the Red Sea survey (Yahel et al. 1998). Estimates of ascidians in our study may have been more accurate than those of the sponges because most of the ascidian species were solitary species, making it easy to count syphons on surfaces, whereas sponges inside crevices and within coral heads were not counted, resulting in their underrepresentation. If these suspension feeders actively pumped water at a constant rate throughout the $6 \mathrm{~h}$ experiments and the efficiency of removal of particles remained constantly high (Reiswig 1971, Ribes et al. 1998b, 1999, Coma et al. 2002) then over this natural range of particle concentration we would expect a firstorder decay, similar to the observed trends (Fig. 2). Also, other researchers have observed that particle-

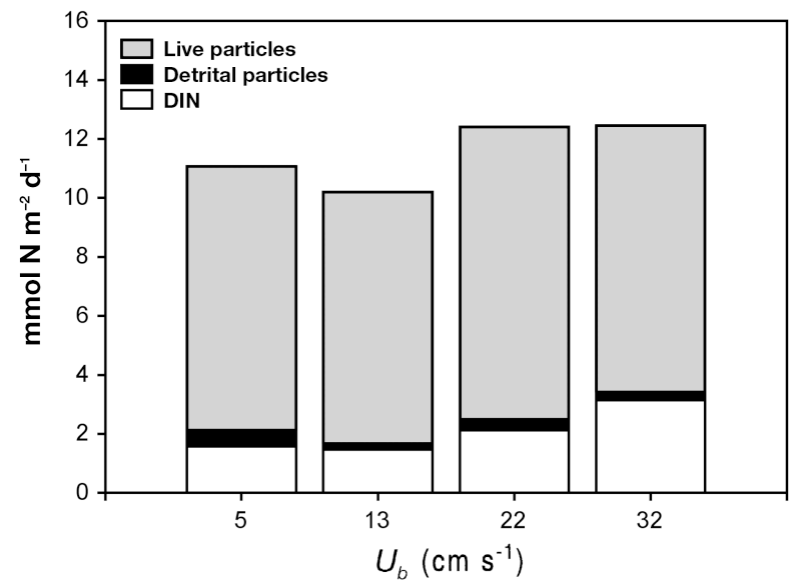

Fig. 4. Total nitrogen removal $\left(\mathrm{mmol} \mathrm{N} \mathrm{m}^{-2} \mathrm{~d}^{-1}\right)$ as dissolved inorganic nitrogen (DIN) and as detrital and live particles in relation to water velocity $\left(\mathrm{cm} \mathrm{s}^{-1}\right)$ 


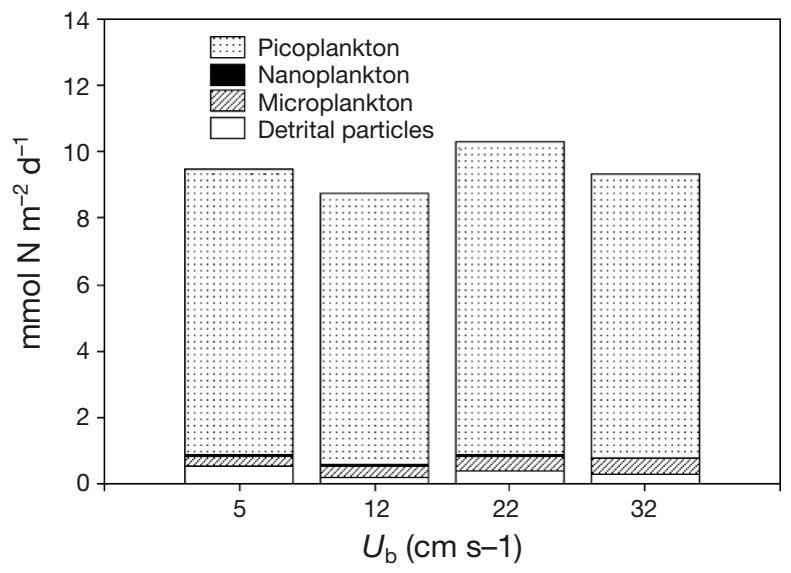

Fig. 5. Nitrogen removal (mmol $\left.\mathrm{N} \mathrm{m}^{-2} \mathrm{~d}^{-1}\right)$ from particles in relation to water velocity $\left(\mathrm{cm} \mathrm{s}^{-1}\right)$. Picoplankton includes heterotrophic bacteria, Synechococcus sp. and picoeukaryotes; nanoplankton comprises nanoeukaryotes, and microplankton comprises diatoms, dinoflagellates and ciliates

capture rates are optimal in narrow ranges of moderate water velocities (Shimeta \& Jumars 1991, Dai \& Lin 1993, Eckman \& Duggins 1993, Fabricius et al. 1995), as indicated by a lower $S$ at $32 \mathrm{~cm} \mathrm{~s}^{-1}$ (Fig. 3) in the present study. The suggestion in the literature is that higher water velocity either deforms filtering structures (Shimeta \& Jumars 1991) or (most probably) creates adverse pressure gradients that inhibit pumping of water (Wildish et al. 1987). Thus, we believe that the removal of particles was primarily controlled by active pumping and filtering of filter-feeders (authors' unpubl. data).

Removal of small living particles, mostly picoplankton, corresponded to an uptake of about $10 \mathrm{mmol} \mathrm{N} \mathrm{m}^{-2}$ $\mathrm{d}^{-1}$, and varied by about $20 \%$ as a function of velocity. This amount of plankton corresponds to only about $60 \mathrm{mmolC} \mathrm{m} \mathrm{d}^{-1}$ (assuming a C:N ratio of 6 ), or heterotrophy, of about $10 \%$ of the daily primary productivity (assuming $600 \mathrm{mmol} \mathrm{C} \mathrm{m} \mathrm{m}^{-2} \mathrm{~d}^{-1}$ ). To compare this rate of nitrogen input to the reef with the typical rates of dissolved inorganic nitrogen uptake, we estimate the dissolved inorganic nitrogen uptake from a knowledge of the rates constants for ammonia and nitrate uptake (Atkinson et al. 1994, Thomas \& Atkinson 1997) measured in the same flumes with similar reef communities. Rate constants (first order with respect to concentration) are related to the friction factor, $C_{f}$, and water velocity, and range between 72 and $144 \times 10^{-6} \mathrm{~m} \mathrm{~s}^{-1}\left(104 \pm 36 \mathrm{SD} \times 10^{-6} \mathrm{~m} \mathrm{~s}^{-1}\right)$ for water velocities from 5 to $37 \mathrm{~cm} \mathrm{~s}^{-1}$. The rate constants for $\mathrm{NH}_{4}{ }^{+}$are 2.4 times higher than for $\mathrm{NO}_{3}{ }^{-}$(Atkinson et al. 1994, Atkinson \& Falter 2003). Dissolved inorganic $\mathrm{N}$ uptake (DIN) was estimated by multiplying appropriate rate constants from the literature $\times$ concentra- tions of ammonia and nitrate typical for Kaneohe Bay (CISNet 2000, Table 2):

DIN uptake $=S_{\mathrm{N}} \times\left[\mathrm{NH}_{4}^{+}\right]+S_{\mathrm{N}} \mathrm{NH}_{4}^{+} / 2.4 \times\left[\mathrm{NO}_{3}^{-}\right]$

Even though the rate constants $\left(S, \mathrm{~m} \mathrm{~s}^{-1}\right)$ for dissolved inorganic uptake were about 2-fold higher than for the particles, the calculated nitrogen removal from particles was higher than the DIN uptake (8.8-10.3 mmol $\mathrm{N} \mathrm{m}^{-2} \mathrm{~d}^{-1}$ for particles compared to 1.5-3.1 mmol $\mathrm{N} \mathrm{m}^{-2} \mathrm{~d}^{-1}$ for DIN [Fig. 4]). This result arose because removal of both particles and ammonia or nitrate depend on both the rate constants and concentrations in the water; in Kaneohe Bay, particles represent $86 \%$ of the total nutrient pool (particulate nitrogen $=2.14 \pm 0.71 \mathrm{mmol} \mathrm{l}^{-1}$, dissolved inorganic nitrogen $=0.34 \pm 0.55 \mu \mathrm{mol} \mathrm{l}^{-1}$ ).

We expect rate constants of uptake for other reefs to be similar in magnitude, but the proportions of particulates to dissolved compounds may change dramatically, depending on the biomass of plankton and the relative amounts of nutrients near a given reef. Concentrations of particulate nitrogen in this

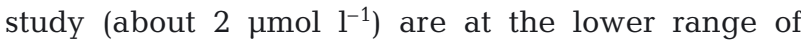
particulate nitrogen over coral reefs (range 1.1 to $9.5 \mu \mathrm{mol} \mathrm{l} \mathrm{l}^{-1}$; Crossland \& Barnes 1983, Crossland et al. 1984), although many more determinations of plankton biomass and particulate nitrogen are required. Thus, it is difficult to make sweeping generalizations regarding the relative proportions of particulate and dissolved $\mathrm{N}$ inputs. Also, assimilation efficiencies of particulate nitrogen for the associated fauna taxa in these experiments ranged from 42 to $90 \%$, depending on the nutritional content of the particles (e.g. Klumpp 1984, Zamer 1986, FialaMedioni 1987). Even when half the particulate nitrogen is not assimilated and released or remineralized, particulate nitrogen is still a major source of nitrogen. It is clear from these experiments that for Hawaiian reefs, and probably for most reefs situated in low-nutrient water, picoplankton is a major source of nutrients but a minor source of carbon.

Acknowledgements. This paper was funded in part by the NOAA project \#R/CR-1, which is sponsored by the University of Hawaii Sea Grant College Program, SOEST, under Grant \#NA 86RG0041. Additional funding was provided by CISNet (NOAA project \#NA 870A0531). We especially thank Jim Fleming for his help with the flume operation and throughout the study. Thanks to Dr. Fenny Cox and the people of the Point lab (HIMB) for a pleasant working environment and valuable discussions. The flow cytometry measurements were carried out at the CMIMA-CSIC (Barcelona, Spain) with the assistance of Pep Gasol. Support for this work was provided by a Postdoctoral Fellowship from the 'Ministerio de Educación y Cultura (MEC)' to M.R. and by a research contract from MEC to R.C. This is HIMB contribution 1163 and SOEST contribution 6210 . 


\section{LITERATURE CITED}

Alldredge AL, Silver MW (1988) Characteristics, dynamics and significance of marine snow. Prog Oceanogr 20:41-82

Atkinson MJ, Falter J (2003) Biogeochemistry of coral reefs. In: Black K, Shimmield G (eds) Biogecochemistry of marine ecosystems. Sheffield Academic Press, Sheffield (in press)

Atkinson MJ, Kotler E, Newton P (1994) Effects of water velocity on respiration, calcification, and ammonium up-take of a Porites compressa community. Pac Sci 48: 296-303

Ayukai T (1995) Retention of phytoplankton and planktonic microbes on coral reefs within the Great Barrier Reef, Australia. Coral Reefs 14:141-147

Baird ME, Atkinson MJ (1997) Measurement and prediction of mass transfer to experimental coral reef communities. Limnol Oceanogr 42:1685-1693

Bilger RW, Atkinson MJ (1992) Anomalous mass transfer of phosphate on coral reef flats. Limnol Oceanogr 37:261-272

Button DK (1994) The physical base of marine bacterial ecology. Microb Ecol 28:272-285

Caron DA, Dam HG, Kremer P, Lessard EJ and 6 others (1995) The contribution of microorganisms to particulate carbon and nitrogen in surface waters of the Sargasso Sea near Bermuda. Deep-Sea Res 42:943-972

Cho BC, Azam F (1990) Biogeochemical significance of bacterial biomass in the ocean's euphotic zone. Mar Ecol Prog Ser 63:253-259

Coma R, Ribes M (2003) Seasonal energetic constraints in Mediterranean benthic suspension feeders: effects at different levels of ecological organization. Oikos 101: 205-215

Coma R, Ribes M, Gili JM, Zabala M (2002) Seasonality of in situ respiration rate in three temperate benthic suspension feeders. Limnol Oceanogr 47:324-331

Crossland CJ, Barnes DJ (1983) Dissolved nutrients and organic particulates in water flowing over coral reefs at Lizard Island. Aust J Mar Freshw Res 34:835-844

Crossland CJ, Hatcher BG, Atkinson MJ, Smith SV (1984) Dissolved nutrients of a high-latitude coral reef, Houtman Abrolhos Islands, Western Australia. Mar Ecol Prog Ser 14:159-163

Dai CF, Lin MC (1993) The effects of flow on feeding of three gorgonians from southern Taiwan. J Exp Mar Biol Ecol 173:57-69

Eckman JE, Duggins DO (1993) Effects of flow speed on growth of benthic suspension feeders. Biol Bull (Woods Hole) 185:28-41

Edler L (1979) Recommendations for marine biological studies in the Baltic sea: phytoplankton and chlorophyll. Balt Mar Biol 5:5-38

Erez J (1990) On the importance of food sources in coral reef ecosystems. In: Dubinsky Z (ed) Ecosystems of the world, Vol 25. Coral Reefs. Elsevier, Amsterdam, p 411-418

Fabricius KE, Benayahu Y, Genin A (1995) Flow-dependent herbivory and growth in zooxanthellae-free soft corals. Limnol Oceanogr 40:1290-1301

Fabricius KE, Benayahu Y, Yahel G, Genin A (1999) Erratum. Limnol Oceanogr 41:1520

Ferrier-Pagès C, Gatusso JP (1998) Biomass, production and grazing rates of pico- and nanoplankton in coral reef waters (Miyako Island, Japan). Microb Ecol 35:46-57

Ferrier-Pagès C, Allemand D, Gatusso JP, Jaubert J (1998) Microheterotrophy in the zooxanthellate coral Stylophora pistillata: effects of light and ciliate density. Limnol Oceanogr 43:1639-1648
Fiala-Medioni A (1987) Lower chordates. In: Pandian TJ, Vernberg FJ (eds) Animal energetics, Vol 2. Academic Press, San Diego, p 323-356

Gasol JM, Morán XAG (1999) Effects of filtration on bacterial activity and picoplankton community structure as assessed by flow cytometry. Aquat Microb Ecol 16: 251-264

Gast GJ, Wiegman S, Wieringa E, van Duyl FC, Bak RPM (1998) Bacteria in coral reef water types: removal of cells, stimulation of growth and mineralization. Mar Ecol Prog Ser 167:37-45

Genin A, Yahel G, Reidenbach MA, Monismith SG, Koseff JR (2002) Intense benthic grazing on phytoplankton in coral reefs revealed using the control volume approach. Oceanography 15:90-96

Glynn PW (1973) Ecology of a Caribbean coral reef, the Porites reef flat biotope. Part II. Plankton community with evidence for depletion. Mar Biol 22:1-21

Hearn CJ, Atkinson MJ, Falter JL (2001) A physical derivation of nutrient-uptake rates in coral reefs: effects of roughness and waves. Coral Reefs 20:347-356

Hunter CL (1988) Genotypic diversity and population structure of the Hawaiian reef coral, Porites compressa. PhD thesis, University of Hawaii, Manoa

Johannes RE (1974) Sources of nutritional energy for reef corals. Proc 2nd Int Coral Reef Symp 1:133-137

Klumpp DD (1984) Nutritional ecology of the ascidian Pyura stolonifera: influence of body size, food quantity and quality on filter-feeding, respiration, assimilation efficiency and energy balance. Mar Ecol Prog Ser 19:269-284

Lewis JB, Price WS (1975) Feeding mechanisms and feeding strategies of Atlantic reef corals. J Zool 176:527-544

Loya Y (1978) Plotless and transect methods. In: Stoddart DR, Johannes RE (eds) Coral reefs: research methods. UNESCO, Paris, p 197-217

Montagnes DJ, Berges SJA, Harrison PJ, Taylor FJR (1994) Estimating carbon, nitrogen, protein and chlorophyll a from volume in marine phytoplankton. Limnol Oceanogr 39:1044-1060

Muscatine L (1973) Nutrition of corals. In: Jones OA, Endean R (eds) Biology and geology of coral reefs, Vol 2. Academic Press, New York, p 77-115

Olson RJ, Chisholm SW, Zettler ER, Armbrust EV (1990) Pigments, size, and distribution of Synechococcus in the North Atlantic and Pacific Oceans. Limnol Oceanogr 35: 45-58

Patterson MR (1984) Patterns of whole colony prey capture in the octocoral, Alcyonium siderium. Biol Bull (Woods Hole) 167:613-629

Pile AJ (1997) Finding Reiswig's missing carbon: quantification of sponge feeding using dual-beam flow cytometry. Proc 8th Int Coral Reef Symp 2:1403-1410

Porter JW (1974) Zooplankton feeding by the caribbean reefbuilding coral Monastrea cavernosa. Proc 2nd Int Coral Reef Symp 1:111-125

Reckermann M, Colijn F (2000) Aquatic flow cytometry: achievements and prospects. Sci Mar 64:119-265

Reiswig HM (1971) Particle feeding in natural populations of three marine demosponges. Biol Bull (Woods Hole) 141: $568-591$

Ribes M, Coma R, Gili JM (1998a) Heterotrophic feeding by gorgonian corals with symbiotic zooxanthellae. Limnol Oceanogr 43:1170-1179

Ribes M, Coma R, Gili JM (1998b) Seasonal variation of in situ feeding rates by the temperate ascidian Halocynthia papillosa. Mar Ecol Prog Ser 175:201-213

Ribes M, Coma R, Gili JM (1999) Natural diet and grazing rate 
of the temperate sponge Dysidea avara (Demospongiae, Dendroceratida) throughout an annual cycle. Mar Ecol Prog Ser 176:179-190

Sebens KP, Vandersall KS, Savina LA, Graham KR (1996) Zooplankton capture by two scleractinian corals, Madracis mirabilis and Monastrea cavernosa, in a field enclosure. Mar Biol 127:303-318

Sebens KP, Grace SP, Helmuth B, Maney EJ Jr, Miles JS (1998) Water flow and prey capture by three scleractinian corals, Madracis mirabilis, Monastrea cavernosa and Porites porites, in a field enclosure. Mar Biol 131:347-360

Sherr EB, Sherr BF, Sigmon CT (1999) Activity of marine bacteria under incubated and in situ conditions. Aquat Microb Ecol 20:213-223

Shimeta J, Jumars PA (1991) Physical mechanisms and rates of particle capture by suspension feeders. Oceanogr Mar Biol Annu Rev 29:191-257

Sorokin YI (1973) Trophical role of bacteria in the ecosystems of the coral reef. Nature 242:415-417

Stimson J, Kinzie III RA (1991) The temporal pattern and rate of release of zooxanthellae from the reef coral Pocillopora damicornis (Linnaeus) under nitrogen-enrichment and control conditions. J Exp Mar Biol Ecol 153:63-74

Editorial responsibility: Charles Birkeland (Contributing Editor), Honolulu, Hawaii, USA
Thomas FIM, Atkinson MJ (1997) Ammonium uptake by coral reefs: effects of water velocity and surface roughness on mass transfer. Limnol Oceanogr 42:81-88

Tremblay JE, Legendre L (1994) A model for the size-fractioned biomass and production of marine phytoplankton. Limnol Oceanogr 39:2004-2014

Wildish DJ, Kristmanson DD, Hoar RL, DeCoste AM, McCormick SD, White AW (1987) Giant scallop feeding and growth responses to flow. J Exp Mar Biol Ecol 113: 207-220

Wotton RS (1990) Particulate and dissolved organic matter as food. In: Wotton RS (ed) The biology of particles in aquatic systems. CRC Press, Boca Raton, FL, p 213-261

Yahel G, Post AF, Fabricius K, Marie D, Vaulot D, Genin A (1998) Phytoplankton distribution and grazing near coral reefs. Limnol Oceanogr 43:551-563

Yonge CM (1963) The biology of coral reefs. Adv Mar Biol $1: 209-260$

Zamer WE (1986) Physiological energetics of the intertidal sea anemone Anthopleura elegantissima. I. Prey capture, absorption efficency and growth. Mar Biol 92:299-314

Zar JH (1996) Biostatistical analysis, 3rd edn. Prentice-Hall, Upper Saddle River, NJ

Submitted: August 19, 2002; Accepted: April 24, 2003

Proofs received from author(s): July 28, 2003 